\title{
Indflydelse i arbejdslivet - status, muligheder, alternativer?
}

$\mathrm{I}_{\mathrm{s}}^{\mathrm{s}}$ de formende konflikter på arbejdsmarkedet i slutningen af det 19. århundrede var indflydelse i arbejdet et centralt konfliktpunkt, i Danmark og i den industrialiserede verden i øvrigt. Arbejdsgivere og fagforeninger var i konflikt om, hvem der havde retten til at lede og fordele arbejdet. Med Septemberforliget i 1899 blev Danmark det første land i verden, hvor der blev indgået et nationalt kompromis om indflydelse. Arbejdsgiverne vandt ledelsesretten, og fagforeningerne vandt retten til at forhandle løn og arbejdsvilkår og indgå overenskomster om disse spørgsmål (Galeson, 1955, Christensen et al., 2015).

Dermed var spørgsmålet om indflydelse dog langt fra afklaret. I årtierne efter Septemberforliget tilkæmpede fagforeningerne sig gradvist mere indflydelse. Indflydelsen på løn og arbejdsforhold blev udbygget. Overenskomstsystemet blev mere omfattende. Medarbejderne fik ret til at vælge tillidsrepræsentanter, som arbejdsgiverne havde pligt til at inddrage i beslutningsprocesserne. Samarbejdsudvalg og senere arbejdsmiljøudvalg blev etableret. Endelig fik medarbejdere i aktieselskaber ret til at vælge repræsentanter til selskabernes bestyrelser.

I tiden efter 2. verdenskrig voksede en anden mere konsensusorienteret strømning til udvikling af indflydelse i arbejdet frem. Denne strømning har siden forgrenet sig $i$ variationer og antaget mange forskellige navne, bl.a. Human Relations og Human Resources, Socioteknik, High Performance Work Systems samt Workplace Innovation. En af grundlæggerne var Kurt Lewin, som allerede i 1940erne blev kendt for sin formulering af principper for en involverende arbejdsorganisation og demokratisk ledelse (Lewin et al., 1939). Socioteknikken, som blev udviklet i 1950erne, havde som målsætning at udvikle en arbejdsorganisation, hvor hensynet til det sociale system og det teknisk/økonomiske system var ligeværdigt (Trist \& Bamforth, 1951). En sådan ligeværdighed kunne etableres i en arbejdsorganisation, hvor medarbejderne havde en stor grad af autonomi i et gruppeorganiseret arbejde, samtidig med at medarbejderne havde ansvar overfor virksomheden. Denne strømning har efterfølgende udviklet sig i en lang række skoler og initiativer.

De to hovedstrømninger til udvikling af indflydelse i arbejdet - med fokus på henholdsvis samarbejdet mellem arbejdsmarkedets parter eller fokus på udvikling af ledelse, organisation og teknologi - udfoldes også i dag gennem to tilgange til studier af indflydelse: Employment Relation traditionen (ER) ${ }^{1}$ og Participatory Organization (PO) tilgangen. De to tilgange er overlappende, men retter opmærksomheden lidt forskellige steder hen: ER tilgangen fokuserer på indflydelse på rammerne og vilkårene omkring arbejdet, imens PO tilgangen fokuserer på indflydelse $i$ arbejdet og dets tilretteloeggelse og udførelse.

ER-traditionen fokuserer på den indflydelse, der etableres gennem interessevaretagelse. Her studeres arbejdsmarkedslovgivning, overenskomstsystemet, samarbejdet og konflikterne mellem parterne på arbejdsmarkedet, og hvordan de påvirker løn og arbejdsforhold på den ene side og effektivitet, produktivitet og konkurrenceevne på den anden side. I PO-traditionen studeres deltagelse og indflydelse 
gennem udvikling af arbejdsorganisation, teknologi og ledelse. Indenfor denne tradition er der både et konstruktivt og et kritisk element. I den konstruktive ende studeres det, hvordan organisation og teknologi kan udvikles, så medarbejdernes indflydelse og virksomhedernes effektivitet øges. Det konstruktive element omfatter også en omfattende forskning i hvorledes indflydelse i arbejdet påvirker helbred, læring og fastholdelse på arbejdsmarkedet. Her har Karaseks studier af den betydning indflydelse og læringsmuligheder $\mathrm{i}$ arbejdet har for sundhed og for innovation, været meget betydningsfulde (Karasek \& Theorell, 1990).

I modsætning til ER-traditionen, hvor konfliktende interesser studeres, lægges der i PO-traditionen vægt på de fælles interesser knyttet til indflydelse i arbejdet. PO-traditionen indeholder dog også ganske meget kritisk forskning, fx studeres organisationsformer og teknologier, der kan medvirke til reduktion af indflydelse. Ligeledes studeres modsætningsfyldte elementer i involverende organisationsformer (Sørensen, 2013). For eksempel kan en involverende organisationsform som selvledelse umiddelbart erfares som en udvidelse af indflydelse og autonomi. Selvledelse kan imidlertid samtidig være forbundet med stærk individuel konkurrence. Medarbejderne kan opleve en stor grad af uforudsigelighed. De kan fx få tillagt et ansvar, som de reelt har vanskeligt ved at løfte. Hvis organisationen samtidig domineres af diskurser, der lægger vægt på loyalitet og individuelt ansvar, kan selvledelse og ansvarliggørelse føre til mindre reel indflydelse (Andersen \& Ekman, 2014).

ER-traditionen og PO-traditionen knytter sig til forskellige praksisser i virksomhederne og i arbejdslivet. ER relaterer sig til den praksis, der udfolder sig i etablerede arbejdsmarkedsinstitutioner - overenskomstsystemet, samarbejdssystemet m.v. Her opnår medarbejdere indflydelse gennem deres repræ- sentanter. PO relaterer sig til den praksis, der udfolder sig i arbejdets udførelse, daglig ledelse og forandring. Her kan der udvikles former for direkte indflydelse. Disse to praksisformer understøtter i nogle tilfælde hinanden, men kan i andre tilfælde også optræde som modsætningsfulde praksisser.

Historisk har der fra de organiserede lønmodtageres side været en bekymring for, om den direkte involvering af medarbejdere i ledelsesforhold, ville svække lønmodtagerorganisationerne (Enehaug, Falkum \& Hvid, 2019). Hvis medarbejderne blev personligt ansvarlige for produktivitet og effektivitet risikerede man at solidariteten medarbejderne imellem bliver svækket. Omvendt kan medarbejdere, der gerne vil have mere indflydelse i dagligdagen opleve, at lønmodtagerorganisationer fastholder restriktive faggrænser og etablerede hierarkier.

Indflydelse gennem repræsentanter og direkte indflydelse kan dog også understøtte hinanden. Rettigheder, som forsvares af medarbejderrepræsentanter, kan gøre det lettere for medarbejdere at ytre sig, kritisere og komme med forslag til forandringer, og omvendt kan direkte deltagelse i personalemøder og lignende, give input til medarbejderrepræsentanterne i deres relation til ledelsen. Hvis der kan etableres et positivt samspil mellem direkte deltagelse og repræsentativ deltagelse, synes det at have en positiv effekt på arbejdsmiljøet (Knudsen, Busch \& Lind 2013).

\section{Nye brudflader og muligheder for indflydelse?}

Vi står netop nu i en situation, hvor både interessevaretagelse og direkte deltagelse i arbejdet er under kraftig forandring. Den repræsentative interessevaretagelse, som vi har kendt den i godt 100 år, må nok siges at være svækket, internationalt, men også i Danmark. Neoliberalismen har i årtier sat sit præg på interessevaretagelsens instituti- 
onelle forankring. Nye virksomhedstyper og nye ansættelsesformer, bl.a. båret frem af platformsøkonomien og internationaliseringen af arbejdsmarkedet, har også svækket den repræsentative interessevaretagelse. Men måske opstår der også nye muligheder? I flere af bidragene til dette temanummer peges der på sådanne nye muligheder.

Den direkte indflydelse i arbejdet er også blevet svækket i en årrække af kontrollerende og styrende teknologier og organisationsformer. Hvor de sidste årtiers ledelseskoncepter overvejende udfordrer indflydelsesmuligheder (Hagedorn-Rasmussen \& Klethagen 2019), så er der i de senere år også blevet lanceret nye populære ledelseskoncepter, der forfølger principper om, at organisationer skal bygges op af autonome fællesskaber i arbejdslivet, f.eks. TEAL, Sociokrati og Holakrati (Laloux, 2016, Robertson, 2018). Inden for den offentlige sektor er der en efterspørgsel efter alternativer til NPM. Også demokrati i arbejdet er blevet re-lanceret (\#Democratizingwork 2020, Hvid, Møller \& Ajslev, 2020).

Endelig er der i disse år en udvikling i gang, der som perspektiv vil sprænge opdelingen mellem interessevaretagelse og direkte indflydelse: en ny interesse for udvikling af medarbejderejede kooperativer er vokset frem, internationalt og i Danmark. Her er interesseforskelle mellem ejere og medarbejdere principielt opløst. Medarbejderne har i princippet selv mulighed for at forme arbejdsforhold og arbejdsorganisation. Men også her er der forskellige interesser, erfaringer og perspektiver, der indimellem konflikter. Individuelle interesser relateret til familieforhold, ansættelsessikkerhed m.v. kan være i konflikt med fællesskabets interesser. Styring og kontrol kan også i en medarbejderejet virksomhed udvikle sig til snærende bånd for medarbejderne (Jørgensen, 2020).

Dette temanummer samler 11 bidrag, der belyser forskellige sider af temaet 'indflydelse'. Det har på ingen måde været muligt at komme hele vejen rundt om temaet. Det umuliggør temaets omfang. Temanummeret bliver indledt med to bidrag, der studerer alternative måder til at skabe indflydelse. To meget forskellige alternativer.

Nielsen m.fl. præsenterer i deres artikel med afsæt i et kritisk case, et demokratisk og lighedsorienteret medarbejderejet kooperativ og afdækker herigennem konkrete erfaringer med demokratiske organiseringsformer. I analysen sættes fokus på afgørende aspekter, der synes at indgå i realiseringen af et bæredygtigt kooperativ, herunder betydningen af ejerskab, betydningen af klare procedurer og et klart narrativ, samt betydningen af arbejdstidsnormer og enhedsløn som aspekter af en ny værdimæssig dagsorden. I artiklen sker den en vis opløsning i skellet mellem den repræsentative og den direkte indflydelse. Analysen tager afsæt i en case, hvor indflydelsen $i$ og over arbejdet er meget høj, men adresserer også et opmærksomhedspunkt omkring magtens transformation og herigennem også de risici, der kan ligge i bestræbelserne på at opløse traditionelle magtformer, herunder en kraftig fremvækst af et medarbejderdrevet bureaukratisk apparat.

Clausen præsenterer i sin artikel et historisk eksempel på et forsøg på at skabe et samfundsmæssigt gennembrud for udvikling af indflydelse i arbejdet - nemlig kampagnen for Økonomisk Demokrati i Danmark fra slutningen af 1960erne til slutningen af 1980erne. Et omfattende reformprojekt, som både skulle demokratisere og stabilisere økonomien og skabe indflydelse i arbejdet. Artiklen knytter sig til ER-traditionen, og giver et historisk perspektiv på den aktuelle debat om lighed og demokratisering, som den f.eks. præsenteres af Piketty.

Herefter kommer temanummerets tredje artikel, hvor Wåhlin-Jacobsen anlægger et praxisperspektiv til at videreudvikle forståelsen af indflydelse. Ud fra dette praxisperspektiv er det målet at forstå, hvordan indflydelse 
konkret søges og forhandles på arbejdspladsen med fokus på de sociale mekanismer. Forfatteren placerer praxisperspektivet $\mathrm{i}$ forhold til tre hovedstrømninger inden for forskning i indflydelse og giver et empirisk eksempel på, hvordan man ud fra en etnometodologisk tilgang kan tilgå praxis. Blikket rettes mod hverdagssituationer med henblik på at give fornyet indsigt i de udfordringer, som medarbejdere møder, når de søger indflydelse på deres arbejde og arbejdsplads. Artiklen ligger klart indenfor PO-traditionen.

Temanummeret indeholder desuden to kronikker og to debatartikler:

Grosens kronik knytter sig også til den participatoriske tradition, men med et kritisk udgangspunkt. Grosen viser således, hvorledes teknologiudvikling i den finansielle sektor reducerer indflydelse i arbejdet, men hun peger også på muligheder for, at det kunne være anderledes. Medarbejderrepræsentanter kan have en rolle at spille i en sådan alternativ teknologiudvikling.

Hunts debatartikel balanceres mellem ER-traditionen og PO-traditionen. Hunt præsenterer resultater fra et program, hvor den faglige organisation bidrager til at skabe 'hverdagsaktivisme' på arbejdspladser. Denne hverdagsaktivisme muliggør større indflydelse for medarbejderne i deres arbejde, men kommer også til at styrke den faglige organisation og derigennem også den arena som ER-perspektivet har en særlig opmærksomhed på.
Starheim og Lund skriver sig i deres debatartikel ind i forskellige typer af indflydelsesformer. Med en arbejdsmiljø-prisvindende arbejdsplads som reference, retter de læsernes opmærksomhed i retning af hvilke roller og opgaver for henholdsvis ledelse, medarbejderrepræsentanter og medarbejdere der skal arbejdes med, hvis arbejdspladser vil øge indflydelsesmulighederne. Afsættet er en Arbejdsmiljøkonference, der satte fokus på indflydelse. Selvom indflydelsesdimensionen prises, rejses der også en række afgørende spørgsmål i forhold til de udfordringer, som arbejdet for øget indflydelse kan trække med sig.

Scheuer og Ibsens kronik præsenterer en analyse af magtbalancen mellem arbejdsgiver og lønmodtagere på det offentlige område. Her trækkes der entydigt på ER-traditionen. Det særlige ved den offentlige sektor er, at arbejdsgiveren her ikke alene er en forhandlingspart, men også lovgiver. Derfor har der været bekymringer for, at der ikke er en reel balance mellem interessenterne i den offentlige sektor. Forfatterne afviser imidlertid med deres undersøgelse, at der er en stor ubalance i magtrelationen mellem parterne.

Endelig er der i dette temanummer i alt fem boganmeldelser, hvoraf de fire alle berører problemstillinger, relateret til indflydelse i og over arbejdet. Vi håber, at temanummeret giver læseren inspiration til at tage indflydelse i alle afskygninger, der kan være med til at skabe bæredygtige arbejdsliv. God læselyst!

Peter Hagedorn-Rasmussen, Helge Hvid, Ole H. Sørensen, Rikke Thomsen 


\section{REFERENCER}

Andersen, N. Å., \& Ekman, S. (2014). Den ubundne binding: Fra kontrakt til medarbejderpartnerskab i flygtighedens regime. In C. W. Elmholdt \& M. K. Fogsgaard (red.), Magt i organisationer (pp. 43-61). København: Klim.

Christensen, L. K., Kolstrup, S., \& Hansen, A. E. (2015). Arbejdernes historie i Danmark 18802000. København: Saxo.

\#Democratizingwork (2020). Tilgået d. 22/5-2021, https://democratizingwork.org/

Enehaug, H., Falkum, E., Hvid, H., (2019). Democracy at work. In H. Hvid \& E. Falkum (Red.), Work and Wellbeing in the Nordic Countries. Critical Perspectives on the World's Best Working Lives (pp. 49-66). London: Routledge.

Galenson, W. (1955). Arbejder og Arbejdsgiver $i$ Danmark. København: H. C. Ørsted.

Hagedorn-Rasmussen, P. \& Klethagen, P. (2019). International management concepts meeting Nordic working life. I Work and Wellbeing in the Nordic Countries (pp. 92-114). London: Routledge.

Hvid, H., Møller J. L., Ajslev, J. (2020). Demokratisering af arbejdet. En folkestyret hverdag. København: Frydenlund.

Jørgensen, A.P. (2020). Medejer. Kunsten at overhale konkurrenterne gennem demokratisk ejerskab. København: Gyldendal.

Karasek, R. \& Theorell, T. (1990): Healthy Work. Stress, Productivity and the Reconstruction of Working Life, New York: BasicBooks.
Knudsen, H., Busck, O., Lind, J., (2013). Hvor kommer det gode arbejdsmiljø fra? Fokus på deltagelse og demokrati. Tidsskrift for arbejdsliv, 15(1), 12-31. https://doi.org/10.7146/tfa. v15i1.108924

Laloux, F. (2016): Reinventing organizations: an illustrated invitation to join the conversation on next-stage organizations. Massachusetts: Nelson Parker.

Lewin, K., Lippit, R. \& White, R. (1939). Patterns of aggressive behaviour in experimentally created social climates. Journal of Social Psychology, 10(2), 271-301.

Robertson, B. J. (2018). Holacracy: det banebrydende nye ledelsessystem til en verden i hastig forandring. København: Direction Books.

Sørensen, OH (2013). Direkte medarbejderindflydelse ved organisatorisk forandring - konsekvenser for arbejdsmiljøet, Tidsskrift for Arbejdsmiljø, 13(1), 32-51. https://doi.org/10.7146/tfa.v15i1.108925

Trist, E. \& Bamforth, K. (1951). Some Social and Psychological Consequences of the Longwall Method of Coal-Getting. An Examination of the Psychological Situation and Defences of a Work Group in Relation to the Social Structure and Technological Content of the Work System. Human Relations, 4(1), 3-38. https:// doi.orgflo.1177/00187267510040

\section{NOTER}

1. Tidligere kaldet Industrial Relation traditionen 